\title{
Buddhist Entrepreneurs in the Pandemic Covid-19
}

\author{
Lufina Mahadewi ${ }^{1, *}$ Surachman ${ }^{2}$ Djumilah Hadiwidjojo ${ }^{3}$ \\ Nur Khusniyah Indrawati ${ }^{4}$
}

\author{
${ }^{1,2,3,4}$ Brawijaya University, Indonesia \\ *Corresponding author. Email: mahadewilufina@gmail.com
}

\begin{abstract}
The purpose of this study is to understand and reveal the role of religious values for Buddhist entrepreneurs on a small business scale in entrepreneurial enforcement in the era of the covid-19 pandemic. The research setting is Buddhist entrepreneurs on a small business scale in Bekasi City, Indonesia. The research paradigm is an interpretive phenomenology that emphasizes meaning and understanding in the reality of Buddhist entrepreneurs who can maintain their business in the era of the COVID-19 pandemic. The findings of this study suggest that religious values play a role in shaping entrepreneurial attributes and the ability of entrepreneurial resources of Buddhist entrepreneurs to survive in the Covid-19 Pandemic era. The attributes are manifested in benevolent paternalism style, emphasizing preserving employee weal as a form of embodiment of the Buddhist value, namely Dana. The attributes of economically inherent in Buddhist entrepreneurs as a form of embodiment of the attitude of simplicity in Buddhism provide financial resources to survive in the era of the covid-19 pandemic. This study illustrates that religiosity underlies the competitiveness of Buddhist entrepreneurs through the application of universalism, self-direction and security values that underlie the interaction of values and entrepreneurial attributes in the face of the Covid-19 Pandemic era. This research strengthens the value theory on the phenomenon that reveals and explores religious construct factors in underlying entrepreneurial values.
\end{abstract}

Keywords: Religious Values, Benevolent Paternalism, Entrepreneurial Attributes, Buddhist Entrepreneurs.

\section{INTRODUCTION}

Micro, small and medium enterprises (MSMEs) act as catalysts for the Indonesian economy. MSMEs has major contributions to the increment of Indonesia's GDP, but this increase was not in line with business developments where many of these businesses went bankrupt and eventually closed their businesses during the Covid-19 pandemic. One of the Ministry of Cooperatives and Small and Medium Enterprises policies is to encourage an increase in business scale from micro to small businesses, which is expected to encourage national economic growth. According to Shaw and Conway (2000) [1], small businesses have complex and multidimensional problems ranging from character, competence, internal organization, organizational resources and infrastructure, business network configurations as well as problems due to low entrepreneurial values [2]. Entrepreneurial attributes affect the operationalization of entrepreneurship and resilience in dealing with uncertain situations.
Based on the 2016 economic census, $97.3 \%$ of business actors in Bekasi City are Small and Medium Enterprises (SME). The majority are engaged in the service sector. Data from the Bekasi City Cooperatives and SMEs Office showed that the number of SMEs in Bekasi City in 2018 engaged in services was grew by $16.5 \%$ from the previous year. The Covid-19 pandemic had a major impact on small businesses in Bekasi City. According to the Deputy Mayor of Bekasi, Bekasi City's economic indicators had shown a deflation of 0.1 percent which had an impact on the decline in the purchasing power. Thus, impacting on the sustainability of SMEs in Bekasi City. Among the failures of small businesses in Bekasi City during the Covid-19 pandemic, there are several Buddhist entrepreneurs who are able to sustain their business. This business sustainability is motivated by entrepreneurial attributes which are characterized by internal manifestations of religiosity.

Fabeil et al., (2020) [3] stated limitation of studies on the impact of crises such as pandemics on micro 
and small businesses. The entrepreneurial processes are believed to be based on personal values and beliefs [4]. Thus, provide insight into the large role of personal attribute values and beliefs in entrepreneurial processes in Pandemics era. Religion as a collection of a culture consisting of beliefs, values and norms that act as components of people's lifestyles and rules in individuals who comprehend religious values into business practices and work environments [5] [6] [7]. Individuals who believe in and adhere to religious principles and values will undertake these principles in the practice of daily life, including in business [8]. Previous studies using the interpretive paradigm have not discussed specifically the manifestation of religious values in the characteristics of entrepreneurship in the crisis era. The research aims to fill the gap in revealing the entrepreneurial characteristics in the crisis era formed from the internalization of religious values in Buddhism. These characteristics are manifested in the form of management style and entrepreneurial decisions to survive in a pandemic situatio

The research argument is the phenomenon of entrepreneurial sustainability of Buddhist entrepreneurs on a small business scale in Bekasi city in the covid-19 pandemic. The business continuity is motivated by the attributes of Buddhist entrepreneurs colored by the embodiment of religious values. Buddhist entrepreneur's belief of the Four Noble Truths Buddhism shape the entrepreneurial attributes in responding to uncertain conditions as of pandemic outbreak. The Buddhist perspective provides directions for using resources and financial policies in surviving pandemic situations with welfare as the objective. This study reveals the application of religious values in the context of Buddhism in shaping entrepreneurial attributes and resources to survive in crises.

\section{LITERATURE REVIEWS}

The religious context in entrepreneurship had three perspectives: a synthesis moderating entrepreneurial environment, an embodiment of belief reflected in entrepreneurial behavior, and a symbol of entrepreneurship form [9]. Hofstede (1991) [10] introduced the concept of culture as a major dimension in describing organizational behavior. Culture owns a vital role in achieving organizational excellence [11]. Culture emerged when the individuals involved have a shared history and similarities in language, experience, religion, ethnicity [12], initialized self-attitudes and social behavior.

Religion is a repository of sacred values comprises cultural and spiritual views systems determining economic thought in business management, leadership styles and decision making [13] [14] [15] [16] [17] [18]. Religious orientations form a value system [19] and as a synthesis of entrepreneurial relationships in the process and rationalization of business decision-making such as risk and market research [8]. The level of religiosity affects entrepreneurs' competitiveness by applying the values of universalism, self-direction, and security. Thus, provides support of level of religiosity in affecting the relationship between values and entrepreneurial attributes. Religious values construct the entrepreneurs values pattern. The spiritual goals are determined by meaning, the coherence of composed by values, beliefs, attitudes, and behavior [19] [20]. The concept of value used as a basis to explain the function of religion in shaping entrepreneurial behavior through the influence of intrinsic motivation. This perspective provides relevance to phenomena that reveal and explore religious orientations in the formation of entrepreneurial attributes of Buddhist entrepreneurs in facing the uncertain era of the COVID-19 pandemic.

Buddhism refers to Dhamma in which the basis of economic activities are the ethical values of an economic activity and the consideration of dynamic and complex causal processes that shape reality [21]. Economic activity is an interrelated whole subjected to a natural law and leads to harmony [21]. Buddhism has the basis of Catvari Arya Satyani or the Four Noble Truths [22] which consists of (1). Duhkha Aryasatya of the Noble Truth in the presence of suffering, (2). Duhkha Samudaya Aryasatya of the Noble Truth at the origin of suffering (3). Duhkha Nirodha Aryasatya of the Noble Truth at the cessation of suffering, (4). Duhkha Nirodha Gaminipratipad Aryasatya of the Noble Truth of the Noble Eightfold Path for the elimination of suffering.

Yarnall (2003) [23] pointed entrepreneurial motivation in Buddhism lies in fulfilling business challenges without being attached to the business demands and adapting the principles and values of Buddhism. This research aims to illustrate the determination of Buddhist entrepreneurs in fulfilling religious principles through entrepreneurial attributes as efforts to maintain business in the pandemic era. 


\section{METHODOLOGY}

This phenomenological research uses the Creswell et al., (2007) [24] stages, which begin by exploring the phenomenon of Buddhist entrepreneurs who survive in the COVID-19 pandemic. The implementation of the research considers and specializes in the expansion of the psychological aspects of phenomenology. The bracketing process places phenomena in a basket intending to separate things that can interfere with the purity of the results through a consideration of relevance to the theme's description.

Data is collected from Buddhist entrepreneurs who have experience in the form of in-depth interviews with Buddhist entrepreneurs who were able to sustain their business during Pandemic Covid19. Buddhist entrepreneurs were asked general questions regarding their experience in manifesting religious values in the embodiment of entrepreneurial attributes in facing the pandemic era and the situation influenced them. The analysis of data and the synthesis of meaning emphasized on how Buddhist entrepreneurs experience the context of religion in forming the entrepreneurial attributes in the pandemic era. The Buddhist values were used as explanations and reinforcers of phenomena as their emergence in entrepreneurial attributes in the pandemic era. The questions are designed to be informal and an interactive process using open-ended comments and questions. Additional questions were prepared relating to the answers of Buddhist entrepreneurs. Clarification will be made through questions or reflection statements to check the accuracy of the information submitted.

\section{DISCUSSIONS}

Buddhist entrepreneurs emphasize their entrepreneurship by collecting virtues to achieve freedom. In the Sigalovada Sutta, Buddhist values believe that the achievement of economic goals underlies the desire of the individual to work hard optimally for material pursuits and set aside the material as savings for the future. The resulting economic materials are used to support the family, focusing on utilizing every expenditure by avoiding waste [25]. Buddhist entrepreneurs in this study does not emphasize the accumulation of material wealth, but on the pursuit of the purpose of life in the form of virtues.
Economic decisions in Buddhism is the embodiment of karma in which the influence of decisions affecting entirety of life aspects [21]. In Buddhism, economic decision is a qualitative consideration based on causal relationships. Economic decisions shall not only notice to the fulfillment of production and consumption [21]. The Buddhist Economics conception views of impermanence (Annica) regarding risk. The concept of Annica imposes a meaning that life consists of various elements influencing and depending on each other [26]. Karma is perceived as a cumulative effect of merit and deprivation determining individuals' destiny [27].

Buddhist entrepreneurs in this study believe that the business conditions during the Covid-19 Pandemic are a manifestation of the truth of Dukkha. Buddhism focuses on the essence and way to relieve suffering and describes the view of the truth of Dhamma in the Four Noble Truths. Buddhist entrepreneurs believe that entrepreneurial conditions during the Covid-19 Pandemic is inevitable suffering. Economic activity in entrepreneurship is believed will continue to experience changes that may cause suffering. One of the causes of suffering in Buddhism is the excessive desire that creates a burden. Therefore, Buddhist entrepreneurs instill a realistic and hopeful attitude that happiness in entrepreneurship is achieved through a personal effort by letting the attachment of the excessive pursuit of desire and condition in entrepreneurship.

The pragmatic depiction of the truth of the Dhamma provides Buddhist entrepreneurs a psychological view to remove defilements and insight of reality of true happiness. The experiences of Buddhist entrepreneurs form an understanding of the entrepreneurship phenomenon as a circle of life or Bhavachakra, which signifies the interdependent condition of suffering. Through this view, Buddhist entrepreneurs show an entrepreneurial nature in facing the crisis-era in the Covid-19 Pandemic through personal efforts in the form of resilience and acceptance of the reality of business conditions. The condition of entrepreneurship is believed to be a phenomenological experience of impermanence that is not tied to certain conditions.

Buddhist entrepreneurs in this study apply the Right Livelihood choices in Buddhism in their entrepreneurship as a manifestation of the implementation of other elements of the Noble Eightfold Path, namely Right Thoughts, Right Actions 
and Right Speech in personal and social life. The enforcement of Right Livelihood Buddhism is perceived as an effort to relinquish suffering. Buddhist entrepreneurs believe that the Covid-19 pandemic is a form of suffering (Dukkha); therefore, through the application of Right Livelihood Buddhism and developing attitudes of patience constitute an effort to accept the entrepreneurial conditions during the Covid-19 Pandemic and release suffering in Buddhism perspective.

The casual relationship between individual behavior and its consequences through the law of cause and effect, views of interdependence and impermanence of Buddhism shape the entrepreneurial attributes of Buddhist entrepreneurs in facing COVID-19 pandemic. The belief of causal relationship of Karma provides an understanding that the entrepreneurial condition during the Covid-19 Pandemic is a cause and effect that arises from the Karma possessed by Buddhist entrepreneurs. Therefore, Buddhist entrepreneurs seek to instill good Karma through entrepreneurial practices undertaken in the era of the covid-19 pandemic emphasizing on achieving prosperity with maximum effort.

Entrepreneurship practices carried out in accordance with religious values will make the karmic conditions in the past realized through efforts to accumulate good karma. One of them is the embodiment of the efforts of Buddhist entrepreneurs to retain employees, which is shown in the form of benevolent paternalism. Buddhist entrepreneurs incur efforts to increase employees internal capacity as a form of paternalistic benevolent management. Those efforts are an approach for Buddhist entrepreneurs to prepare for employee independence by considering their business conditions during Pandemic Covid-19. Buddhist entrepreneurs believe that the achievement of entrepreneurship material is used to practice the achievement of the true meaning of welfare through applying attributes in entrepreneurship by doing benevolence to employees in the form of benevolent paternalistic relationships. In benevolent paternalism, leadership characteristics are shown by treating members as family and giving overall attention to the welfare of members to create attachment and commitment [28] [29] [30].

In Digha Nikaya iii.189-192, the Sigalovada Sutta on how superiors treat employees is providing care when sick. Therefore, the form of its manifestation is to provide concern with efforts to maintain the welfare of employees during the covid-19 pandemic.
The Buddhist conception of the development of loving-kindness or Metta underlies the formation of paternalistic benevolent leadership of Buddhist entrepreneurs. These findings are in line with studies by Cheng et al., 2004 [28] ; Farh et al., 2008 [29]; Bedi, 2020 [30]; Chen et al., 2014 [31] that leadership is shown through caring for its members during times of crisis. The benevolent leadership of Buddhist entrepreneurs and creating engagement with employees is also shown as a means of virtue that creates good karma which is expected to provide a causality for business continuity in the era of the Covid-19 Pandemic. Entrepreneurial characteristics are also highlighted by the direct involvement of Buddhist entrepreneurs in leading during the Covid19 Pandemic. Buddhist entrepreneurs directly provide direction and position themselves as directors and decision makers by involving employees in shaping the entrepreneurial learning process during the Pandemic era.

The paternalistic benevolence of the entrepreneurial attributes of Buddhist entrepreneurs provides employees with awareness and intrinsic motivation for a sense of ownership of the entrepreneurship. In the narratives of the experience of Buddhist entrepreneurs, the working employees are loyal employees who have worked for decades and with the paternalistic relationship pattern formed, employees exemplify a sense of responsibility and togetherness in entrepreneurship during Pandemic era. This study describes the organizational climate of Buddhist entrepreneurship on the characteristics of organizational culture [32] on the description of employee sentiment on the relationship with business owners.

The characteristics of Buddhist entrepreneurs during the covid-19 pandemic are also shown through conservative characteristics of economic attributes. Buddhist entrepreneurs adopt a simple and economic lifestyle as in Buddhism's perspective of Samajivita (living a way of life in accordance with income) to apply the normal reality of life that emphasizes selfcontrol. Entrepreneurial attributes of economical and moderation provide a resource capability for Buddhist entrepreneurs to survive during the Covid19 Pandemic. The explanation of Buddhist entrepreneurs illustrates that the conservative, economical attributes possessed by entrepreneurs provide a signal of the limits of internal capabilities to maintain the continuity of entrepreneurship during the Covid-19 Pandemic. According to Buddhist entrepreneurs, their entrepreneurship has developed 
and survived for decades because one of the business precepts is conveying an attitude of economic living that is in accordance with the Buddhist value of moderation.

The entrepreneurial attributes of Buddhist entrepreneurs in benevolent paternalism are characteristics of organizational culture in Luthans (1995) [32] regarding entrepreneurial philosophy in attitudes towards employees. Buddhist entrepreneurs treat employees as partners by emphasizing a sense of belonging, which is expected to be realized through an honest and responsible attitude in helping Buddhist entrepreneurs to survive in the Covid-19 Pandemic era. Entrepreneurial attributes are also shown by the communication patterns of Buddhist entrepreneurs with employees. Buddhist entrepreneurs apply openness to entrepreneurial conditions during the Covid-19 Pandemic, expecting that employees will be involved by providing ideas to maintain business continuity. This communication pattern illustrates the form of a paternalistic relationship where the learning process in entrepreneurship is carried out openly.

In the manifestation of entrepreneurship, Buddhist entrepreneurs apply an economic lifestyle to Buddhism's moderation perspective, which helps generate business savings. The savings is used as a financial resource in surviving during the Covid-19 Pandemic. The findings of this study provide an understanding that business continuity during the Covid-19 pandemic is formed from the internalization of culture in religious values attached to entrepreneurial attributes. In the Pattakama Sutta Buddhism, wealth must be maintained as in the possibility of a business slump due to a crisis situation. Buddhist entrepreneurs believe in the reasonableness of expectations for wealth through applying an economic attitude and accentuation of employee weal during Pandemic Covid-19.

\section{CONCLUSIONS}

This study found the facticity of the construction of Buddhist religious values that appeared in the entrepreneurial attributes of Buddhist entrepreneurs during the Covid-19 Pandemic. This study provides a theoretical perspective and contribution that is relevant to value theory. This study indicates how religious cognitive values underlie the formation of entrepreneurial attributes in a simple and economical life attitude that provides a mechanism for financial resources that help sustain entrepreneurship during the Covid-19 pandemic.

This research also provides theoretical relevance, which reveals the strengthening conception of the role of religious values that underlies human paternalistic management as an actualization of Buddhism values. This theory strengthens the basis for understanding the practice of religious and spiritual applications in the entrepreneurial mindset and values [19] [33] [34] [35] [36]. The spiritual goals of entrepreneurship are determined by meaning, coherence is determined by values, beliefs, attitudes and behavior [19] [20]. The level of religiosity underlies the attributes of entrepreneurship by applying the values of universalism, self-direction and security. The value theory provides relevance to the phenomenon that uncovers and explores the manifestation of religious values underlying the formation of entrepreneurial attributes in an era of crisis. This study contributes to Buddhist entrepreneurs that the religious component reflected in personal identity provides the necessary resources and religious identification reveals commitments to entrepreneurial action in increasing the sustainability of entrepreneurship during the Covid-19 Pandemic era. Buddhist entrepreneurs attain the convenience of religious values as an accelerator for entrepreneurship continuity during the pandemic.

\section{REFERENCES}

[1] Shaw, E., \& Conway, S., Networking and the small firm. Enterprise and small business, pp. 367-383, 2000.

[2] Kirby, D. A., Entrepreneurship education: can business schools meet the challenge? Education+ training, 2004. DOI: https://doi.org/10.1108/00400910410569632

[3] Fabeil, N. F., Pazim, K. H., \& Langgat, J., The impact of Covid-19 pandemic crisis on microenterprises: Entrepreneurs' perspective on business continuity and recovery strategy. Journal of Economics and Business, vol. 3(2), 2020.

DOI:

https://doi.org/10.31014/aior.1992.03.02.241

[4] Candland, C., Faith as social capital: religion and community development in Southern Asia. Policy sciences, vol. 33 (3), pp. 355-374, 2000. DOI: https://doi.org/10.1023/A:1004857811117

[5] Byrne, C. J., Morton, D. M., \& Dahling, J. J., Spirituality, religion, and emotional labor in the 
workplace. Journal of management, spirituality \& religion, 8(4), pp. 299-315, 2011. DOI: https://doi.org/10.1080/14766086.2011.630169

[6] Miller, D. W., \& Ewest, T., Rethinking the impact of religion on business values: Understanding its reemergence and measuring its manifestations. In Dimensions of Teaching Business Ethics in Asia, Springer, Berlin, Heidelberg, pp. 29-38, 2013. DOI: https://doi.org/10.1007/978-3-642-36022-0_3

[7] Griebel, J., Park, J., \& Neubert, M., Faith and work: An exploratory study of religious entrepreneurs. Religions, vol. 5(3), pp. 780-800, 2014. DOI: https://doi.org/10.3390/rel5030780

[8] Nwankwo, S., \& Gbadamosi, A. Faith and entrepreneurship among the British AfricanCaribbean: Intersections between religious and entrepreneurial values. Journal of Small Business and Enterprise Development, vol. 20(3), pp. 618-633, 2013. DOI: https://doi.org/10.1108/JSBED-04-2013-0066

[9] Dodd, S. D., \& Seaman, P. T., Religion and enterprise: An introductory exploration. Entrepreneurship theory and practice, vol. 23(1), pp. 71-86, $1998 . \quad$ DOI: https://doi.org/10.1177/104225879802300104

[10] Hofstede, G. Organizations and cultures: Software of the mind. McGrawHill, New York, (1991)

[11] Schein, E.H., Organizational Culture and Leadership. 3rd Edition, Psychology, San Diego, CA: Academic Press, Jossey-Bass, San Francisco, pp. 1-66, 2004.

[12] Schein E. The corporate culture survival guide. San Francisco: Jossey-Bass Publishers, 1999.

[13] Weaver, G. R., \& Agle, B. R., Religiosity and ethical behavior in organizations: A symbolic interactionist perspective. Academy of management review, vol. 27(1), pp. 77-97, 2002.

DOI: https://doi.org/10.5465/amr.2002.5922390

[14] Fernando, M., Religion's influence on decisionmaking: evidence of influence on the judgment, emotional and motivational qualities of Sri Lankan leaders' decision-making, 21st European Group of Organization Studies (EGOS) Colloquium, Germany: Freie Universitat Berlin, Berlin, pp. 1-17, 2005.
[15] Bornstein, B. H., \& Miller, M. K., Does a judge's religion influence decision making? Court Review, vol. 45, pp.112-116, 2010. DOI: https://doi.org/10.1179/0075891413Z.00000000 019

[16] Payne, S., Leadership and spirituality: business in the USA. International Journal of Leadership in Public Services, vol. 6 (2), pp. 68-72, 2010. DOI: https://doi.org/10.5042/ijlps.2010.0355

[17] Roman, M., \& Goschin, Z., Does religion matter? Exploring economic performance differences among Romanian emigrants. Journal for the Study of Religions and Ideologies, vol. 10(30), pp. 183-212, 2011.

[18] Liu, J., \& Wilson, J. A., The impact of culture and religion on leadership and management training: a comparison of three continents. Jurnal Pengurusan, vol. 33, pp. 29- 36, 2011. DOI: https://doi.org/10.17576/pengurusan-201133-04

[19] Rokeach, M., The nature of human values. Free press. 1973

[20] Schwartz, S. H., Universals in the content and structure of values: Theoretical advances and empirical tests in 20 countries. In Advances in experimental social psychology, Academic Press. vol. 25, pp. 1-65, 1992. DOI: https://doi.org/10.1016/S0065-2601(08)60281-6

[21] Payutto, P., \& Evans, B. Buddhist economics--a middle way for the marketplace, 1994.

[22] Singgih, Marga, Tridharma Selayang Pandang. Jakarta: Perkumpulan Tridharma, 2017.

[23] Yarnall, T. F., Engaged Buddhism: New and improved? Made in the USA of Asian materials. Action dharma: New studies in engaged Buddhism, pp. 286-344, 2003.

[24] Creswell, J. W., Hanson, W. E., Clark Plano, V. L., \& Morales, A., Qualitative research designs: Selection and implementation. The counseling psychologist, 35(2), pp. 236-264, 2007. DOI: https://doi.org/10.1177/0011000006287390

[25] Walshe, M. O. C., \& Liu, W., Ajaran Budha dan Kematian. Cetakan Pertama, Yogyakarta: Vidyāsenā Production, 2010.

[26] Mukti, K. W., Wacana Buddha Dhamma. Jakarta: Yayasan Dharma Pembangunan, 2003. 
[27] Scarborough, J., Comparing Chinese and western cultural roots: Why" east is east and...". Business Horizons, vol. 41(6), pp. 15-15, 1998. DOI: https://doi.org/10.1016/S00076813(98)90018-0

[28] Cheng, B.S., Chou, L.F., Wu, T.Y., Huang, M.P., \& Farh, J.L., Paternalistic leadership and subordinate responses: Establishing a leadership model in Chinese organizations. Asian Journal of Social Psychology, 7(1), pp. 89-117, 2004. DOI: https://doi.org/10.1111/j.1467839X.2004.00137.x

[29] Farh, L.J., Liang, J., Chou, L.F., \& Cheng, B.S., Paternalistic leadership in Chinese organizations: Research progress and future research direction. In Leadership and management in China: Philosophies, theories, and practices, Cambridge: Cambridge University Press, pp. 171-205, 2008. DOI: https://doi.org/10.1017/CBO9780511753763.00 8

[30] Bedi, A., A meta-analytic review of paternalistic leadership. Applied Psychology, 69(3), pp. 9601008 , 2020.

DOI: https://doi.org/10.1111/apps.12186

[31] Chen, X.P., Eberly, M.B., Chiang, T.J., Farh, J.L., \& Cheng, B.S., Affective trust in Chinese leaders: Linking paternalistic leadership to employee performance. Journal of Management, 40(3), pp. 796-819, 2014. DOI: https://doi.org/10.1177/0149206311410604
[32] Luthans, F., Organizational Behavior, Seventh Edition, Singapore: Mc Graw - Hill, 1995.

[33] Hambrick, D. C., \& Mason, P. A., Upper echelons: The organization as a reflection of its top managers. Academy of management review, 9(2), pp. 193-206, 1984. DOI: https://doi.org/10.2307/258434

[34] Schein, E. H. Organizational culture American Psychological Association, vol. 45, no. 2, pp. 109, 1990. DOI: https://doi.org/10.1037/0003066X.45.2.109

[35] Angelidis, J., \& Ibrahim, N. An exploratory study of the impact of degree of religiousness upon an individual's corporate social responsiveness orientation. Journal of business ethics, vol. 51(2), pp. 119-128, 2004.DOI: https://doi.org/10.1023/B:BUSI.0000033606.27 489.bf

[36] Kinjerski, V. M., \& Skrypnek, B. J. Defining spirit at work: Finding common ground. Journal of organizational change management,17(1) pp. 26-42, 2004.2 DOI: https://doi.org/10.1108/09534810410511288

[37] Dana, L. P., Entrepreneurship and religion. Edward Elgar Publishing. (Ed.), 2010. DOI: https://doi.org/10.4337/9781849806329 